\title{
An Integrative Model of Place Image, Product Image and Consumer Receptivity
}

\author{
Ratna Roostika ${ }^{*}$, Muafi ${ }^{2}$, and Agnès Retno Permata ${ }^{3}$ \\ ${ }^{1}$ Univesitas Islam Indonesia, Yogyakarta, Indonesia \\ ${ }^{2}$ Univesitas Islam Indonesia, Yogyakarta, Indonesia \\ ${ }^{3}$ Univesitas Islam Indonesia, Yogyakarta, Indonesia
}

\begin{abstract}
Place image as an intangible cue has the power to influence the behavior of the buyer. Place in marketing discipline has been analyzed from country level to regional/territorial level. Focusing on a territorial context, the purpose of this study is to examine the place image effects on both the perception of local product and place as destination to visit. A local hand made batik industry from Yogyakarta is chosen to test the model. By analyzing 110 valid sample using SEM-PLS method, some findings from this study are: 1) Place image influences local product beliefs. 2) Product beliefs influence product choice intention. 3) Place image influences place beliefs. 4) Place beliefs influence place visit intention. This study contributes to the place image and product image integration model where majority of previous study were empirically examined as a separate model. By combining place image and its local product image, the local government may design distinct local product marketing strategy align with its local place image.
\end{abstract}

\section{Introduction}

Image as an intangible cue has the power to influence the behavior of buyers. This cue has long been recognized by marketers globally. The development of image theory as behavior influencer has developed starting from product image in micro context to place image as more macro context. Similarly, branding theory also developed from product branding into place branding. Currently it is very common practices that government is using marketing approach to market and to brand their region / city / country. For example, in the more intense tourism competition, many destinations promote their region branding such as I Amsterdam, Be Berlin, I love New York, Jogja Istimewa, and Enjoy Jakarta. In the wider geographical scope, country branding and marketing are also well organized such as $100 \%$ pure New Zealand, Incredible India, and Your Singapore. As part of successful place branding, positive image building is very critical. Place image is used for geographically defined places and it is considered the most macro level application of marketing and branding practices to date. According to Hawkins, et al. [20], images are mental schemata in human memory, that consist of a complex combination of cognitive and affective

* Corresponding author: ratna.roostika@uii.ac.id 
components. In align with this definition, the overall image of a place that is perceived by individual is developed from complex components. In the hospitality literature, the performance of local service sectors, local hospitality, local products quality, local geographical sites and local infrastructures will together make the total image of a place.

The country-of-origin effect on buyers' behavior is particularly because of the positive place image that further affects on product image then further positive attitude for purchase or other positive behaviors. Similarly, country image influences product branding and buyers' positive behaviors. That place-related behavior is influenced by place image has been acknowledged in many tourism researches [25]. At the country level, developed countries have taken many benefits in combining the image power of the country to their products. For example, Korea with its Samsung, Germany with BMW and Mercedes Benz, USA with Ford and General Motor, Italy with Ferrari, Japan with Sony, etc. One country may also powerful in several industries such as Japan with its electronics and automotive and South Korea with its electronics and cosmetics industry. If country-of-origin (COO) works at country level, a narrower context which commonly known as territory-of-origin (TOO) is recently also well practiced and discussed in the marketing literature [30]. The use of TOO is similar to COO perspective, where the image of a territory or region may influence the receptivity of the local products [27]. The TOO concept therefore can be applied by not only well-developed countries but also developing countries as far as they have a strong region image and distinctive products. The marketers can use the region's image to boost its local product sales. In the marketing literature the product country image (PCI) studies have shown that country image helps consumers to evaluate the country's products, which is called as halo effect [18]. The hallo effect is useful and applicable in the situation where consumers are unfamiliar with the foreign products.

However, the study of product country image (PCI) and tourism destination image (TDI) are commonly discussed separately. The studies that relates between place image (destination image) and product image is very limited particularly at the regional or territorial level $[12 ; 28]$. The present study aims to address this research gap by incorporating place image, product beliefs, destination beliefs and the behavioral consequences. More specifically, this study was designed to address these main objectives: 1) to test the influence of place image on product and destination beliefs. 2) to test the product and destination beliefs influence on product and destination receptivity.

\section{Batik Yogyakarta}

In order to achieve the objective of this study, batik industry is chosen to test the model proposed that integrate between place image and local product image. Yogyakarta is one of region in Indonesia which is considered as one of the most favorite tourists' destinations. Yogyakarta is known as cultural city, tourism city as well as student city. In the past time, this region is the center of Mataram Kingdom, and recently the culture and heritage are remained strongly preserved. While the region it self already maintained a good reputation for long, Yogyakarta is also supported by some well known products such as batik, silver, bamboo crafts and many other local foods and culinary. Batik industry is chosen since it is a product that 1) Batik has been part of Javanese long cultural history. 2) Yogyakarta is considered as one of the centers of batik production. 3) Many Batik experts reside in this region. 4) Batik from Yogyakarta has its own uniqueness. Thousands of batik designs have been produced and varieties of batik quality are also offered. The price ranges differently from the cheap one to the very expensive one. Hand write batik is the most expensive kind of batik since it is manually drawn. The less expensive is the stamped batik and a combination between hand written-stamped batik. Majority of batik consumers will 
consider Yogyakarta and the areas surrounding when they need to find good quality batik. For these reasons, this study will test the affect of Yogyakarta, as a city with its wellmaintained image to the receptivity of its Batik industry. It is expected that if the proposed model is accepted, a strategy which combine the strength of place image and the potential local product could be developed.

\section{Literature review}

\subsection{Place image}

Place image has started to become a popular research in the tourism context [7;22]. Place image is defined as the total of beliefs, ideas, and impressions that someone as individual or as a group have on a destination [14]. It is a subjective and also a complex concept where it can be divided into two components namely cognitive (perceptions of individual attributes, for example the quality of services, the friendliness of staff) and affective (overall impressions, for example the emotion or mood towards the destination) [11]. The majority of place image or destination image studies are commonly focused on destination attributes which are used as quantitative or structured data (e.g. [5;17;31]). The main reason for observing image of a destination is to understand the perception of the potential tourists on the destination as well as to understand how tourists will respond by their attitudes and behaviors [11]. Previous research has identified that tourists prefer to choose a destination that has the most favorable image [23]. Recently, the more studies have evidenced on the destination image direct impact on travel behaviors and destination image also plays a critical role in the process of making choice [16].

\subsection{The relationship between place image to product and destination beliefs}

The marketing literature concerning on PCI provides the base for the study of COO [24]. This study, argues that the national origin of a product may influence product evaluations by the consumers. This proposition then leads to the theoretical foundation for country of origin (COO) effect on consumer behaviors. After this study, research on perceived COO as a cue for consumers product evaluation become proliferated. For example, some researches drew on empirical evidence which identified the moderating effect of COO on consumer by product category (e.g. [1;3]). With this logic, this study uses the PCI framework to examine the contribution of place image (destination image) to product beliefs at regional level. The recent studies, Stepchenkova [29] and Zhang, et al., [31] found that country image affects destination image. Further, the study also found that this positive image affects tourists' visitor intentions. The work of Elliott and colleagues (e.g. [10;9]) have developed more integrative models that combine PCI and TDI to further see the consumer behaviors. The present study follows DeNisco, et al., [8] and Mody, et al., [24] in evaluating the place image effect on products and destination beliefs. These studies found the relationships between place image and product and destination beliefs. More specifically place image affects beliefs [8;9]. In order to explore how consumer perceptions of place image may affect their attitudes on products and destinations beliefs, therefore this study proposes:

H1. Place image has positive influence on product beliefs.

$\mathrm{H} 2$. Place image has positive influence on destination beliefs. 


\subsection{Intention to choose and to visit}

Elliot and Papadopoulos [9] argue that beliefs may affect behavioral intention or receptivity. In the tourism context, this behavior intentions can be translated into several actions such as intention to purchase, intention to choose, intention to recommend, intention to support and intention to visit. Of particular interest here, this study examines the intention to choose the local products as well as the intention to visit the destination. Following DeNisco, et al., [8] and Elliot and Papadopoulos [9] integrative model, this study combined two research streams, 1) consumer perceptions about products, and the other is 2) consumer perceptions on destinations. Previous studies have identified the consecutive relationships starting from place image (cognitive and affective), followed by beliefs and then finally the behavioral action whether to choose or to visit.

\subsection{The relationship between belief and intention to choose/visit}

Beliefs affect behavioral intention or receptivity [9]. The term receptivity is used to incorporate consumers' willingness to buy, to choose, to visit or to travel. Receptivity is also associated with overall assessment of places as producers and tourism destinations. The relationship between destination image and product image has been confirmed in the studies (eg. [4]). Similarly, the relationships from product and destination beliefs to product and destination receptivity also confirmed in some studies (eg. [4;9]). More specifically, the main contribution from this study is the integrative framework, where previous studies only provided empirical test in separate study. For example, study in destination image was not consider the relationship to product image original from the related destination. Similarly, studies on product image rarely relates to destination image of the related products. By incorporating place/destination image, the beliefs and the intention to choose/visit, the local government or travel agency could design marketing strategy that match between local place image and local potential products. Behavioral intentions such as intention to visit a destination is defined as the likelihood where someone is deciding to visit a place [26]. As a concept, the knowledge on behavioral intention is important by both academic researchers and industry since it can be used as a predictor of actual behavior. Kaplanidou [21] identified some previous researches which already observed antecedent of behavioral intentions such as destination image, trust, quality, value, attitude, etc. Beliefs is an attitude when people are already trust in something. Beliefs according to study from Elliot and Papadopoulos [8] and DeNisco, et al., [9] affect behavioral intentions. Product beliefs may affect intention to choose product. For destination belief, it may affect the intention to visit. Therefore, this study further proposes:

H3. Product beliefs has positive influence on intention to choose product

H4. Destination beliefs has positive influence on intention to visit a place

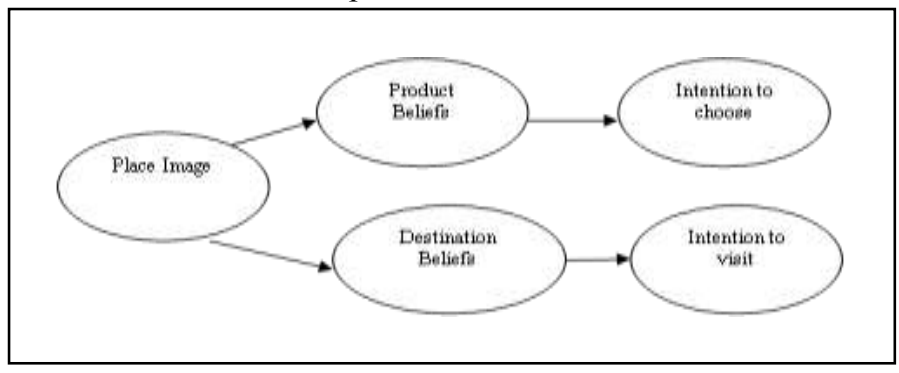

Fig. 1. Research Model 


\section{Research methods}

\subsection{Research instrument}

This study applied quantitative method in order to achieve the objective of the research. A survey method was taken by developing questionnaires and distribute the paper-based questionnaire to respondents who live outside the region of Yogyakarta. The questionnaires were developed from previous studies in the same context which mainly taken from Elliot and Papadopoulos [8] and DeNisco, et al., [9]. This study applies Likert scale for close questionnaire ranging from 1 very disagree to 5 very agree. Purposive sampling method was chosen where respondents should not be the residents of Yogyakarta.

\subsection{Respondents' profile}

After three weeks of data gathering, 110 respondents were successfully gathered and valid for further statistical processes. Table 1 provides data of the respondents' characteristics. As seen from table 1, majority of the respondents are female household. They are between 31-40 years old and they understand very well about Yogyakarta and Batik from Yogyakarta. Majority of the respondents' occupation are "other". After gone through further interview, the meaning of "other" is translated as they don't have permanent job. Sometimes they can get side jobs such as food catering/cooking, sewing, farming, planting, etc. Other can also be interpreted as housewife and no specific job. Even though majority are holding bachelor, but they prefer to be a house wife.

Table 1. Demographic Profile of The Respondents

\begin{tabular}{|l|r|r|r|}
\hline \multicolumn{1}{|c|}{ Demographic } & \multicolumn{1}{|c|}{$\begin{array}{c}\text { Number of } \\
\text { Respondents }\end{array}$} & \% & Cumulative \% \\
\hline Gender & 19 & $17.3 \%$ & $17.3 \%$ \\
Male & 91 & $82.7 \%$ & $100 \%$ \\
Female & 0 & $0 \%$ & 0 \\
\hline Age (Years) & 52 & $47.3 \%$ & $47.3 \%$ \\
$15-30$ & 58 & $52.7 \%$ & $100 \%$ \\
$31-40$ & & & \\
Older than 40 & 0 & $0 \%$ & $0 \%$ \\
\hline Occupational Status & 0 & $0 \%$ & $0 \%$ \\
Students & 1 & $9 \%$ & $38.2 \%$ \\
Public Sector & 41 & $37.3 \%$ & $100 \%$ \\
Private Sector & 68 & $61.8 \%$ & $7.6 \%$ \\
Self Employed & & & $40.0 \%$ \\
Others & 13 & $11.8 \%$ & $79.1 \%$ \\
\hline Monthly Expenditure & 31 & $28.2 \%$ & $100 \%$ \\
Less than Rp. 500.000/mth & 43 & $39.1 \%$ & $18.2 \%$ \\
> Rp. 500.000-1.000.000 & 23 & $20.9 \%$ & $100 \%$ \\
> Rp. 1.000.000-3.000.000 & & & $100 \%$ \\
> Rp. 3.000.000 & 20 & $18.2 \%$ & $100 \%$ \\
\hline Education & 90 & $81.8 \%$ & \\
High School & 0 & $0 \%$ & $0 \%$ \\
Bachelor & 0 & & \\
Master & & & \\
Other & & & \\
& & & \\
\end{tabular}




\subsection{Structural equation modelling}

Partial least squares structural equation modelling (PLS-SEM) was chosen as statistical tool to test the proposed model. Due to the complexity of the proposed model, PLS-SEM is widely used [2]. PLS enable research with non-normal data distributions as well as data with either formative measure or reflective measure [2]. In the areas of marketing, tourism, strategic management, hospitality and behavioral studies, PLS is considered a prominent SEM technique [2;19].

\subsection{Measurement model}

PLS assess two procedures which are measurement model and structural model. That is why we called two step approaches. The measurement model is for testing and preparing data reliability and validity. In measuring construct's reliability, composite reliability (CR) is used and the value should be higher than 0.7 [6]. As can be seen from table 2, composite reliability (CR) were all above 0.7 thus satisfied the requirement of data reliability. The item's reliability is also important which can be seen from the item loadings in table 2 . The item loadings should be higher than 0.50 according to Hair, et al., [19]. Validity of the measure was checked by testing convergent validity, which can be seen from AVE values. AVE value is accepted when the value is above 0.5. Table 2 shows that all AVE value was above 0.5 , or ranging from 0,7023 (destination beliefs) to 0.7776 (intention to visit). The result from the composite reliability can also be translated as the measure for convergent validity for all constructs investigated in the study.

Table 2. Descriptive Statistic of Constructs

\begin{tabular}{|l|l|r|r|}
\hline & \multicolumn{1}{|c|}{ Items } & \multicolumn{1}{c|}{ Loading } & Mean \\
\hline Place Image & & & \\
CR $=0.9241$ & CA1 & 0.8708 & 0.8665 \\
Cronbach Alpha $=0.8953$ & CA3 & 0.9039 & 0.9058 \\
AVE $=0.713$ & CK2 & 0.6028 & 0.5922 \\
& Ck5 & 0.9068 & 0.9005 \\
& CK6 & 0.8968 & 0.8903 \\
\hline Product Beliefs & & & \\
CR $=0.8765$ & PP2 & 0.8849 & 0.8874 \\
Cronbach Alpha $=0.7877$ & PP3 & 0.8831 & 0.8814 \\
AVE $=0.7042$ & PP4 & 0.7414 & 0.7405 \\
\hline Destination Beliefs & & & \\
CR $=0.7854$ & DP1 & 0.848 & 0.8419 \\
Cronbach Alpha $=0.93$ & DP2 & 0.7436 & 0.7392 \\
AVE $=0.7023$ & DP3 & 0.9138 & 0.9137 \\
\hline Intention to Choose & & & \\
CR $=0.8868$ & MMP1 & 0.7589 & 0.7672 \\
Cronbach Alpha $=0.8305$ & MMP2 & 0.8511 & 0.8554 \\
AVE $=0.6625$ & MMP3 & 0.8447 & 0.8457 \\
& MMP4 & 0.7977 & 0.8088 \\
\hline Intention to Visit & & & \\
CR $=0.9129$ & MMD1 & 0.8746 & 0.8689 \\
Cronbach Alpha $=0.8664$ & MMD2 & 0.9068 & 0.9043 \\
AVE $=0.7776$ & MMD4 & 0.8634 & 0.8671 \\
\hline
\end{tabular}


Table 3. AVE Square Root

\begin{tabular}{lcrrrr}
\hline & $\begin{array}{c}\text { Destination } \\
\text { Beliefs }\end{array}$ & $\begin{array}{c}\text { Intention to } \\
\text { Choose } \\
\text { Destination }\end{array}$ & $\begin{array}{c}\text { Intention } \\
\text { to Choose } \\
\text { Product }\end{array}$ & $\begin{array}{c}\text { Place } \\
\text { Image }\end{array}$ & $\begin{array}{c}\text { Product } \\
\text { Beliefs }\end{array}$ \\
\hline Destination Beliefs & $\mathbf{0 . 8 3 8}$ & 0 & 0 & 0 & 0 \\
\hline $\begin{array}{l}\text { Intention to Choose } \\
\text { Destination }\end{array}$ & 0.6983 & $\mathbf{0 . 8 8 1 8}$ & 0 & 0 & 0 \\
\hline $\begin{array}{l}\text { Intention to Choose } \\
\text { Product }\end{array}$ & 0.68 & 0.8079 & $\mathbf{0 . 8 1 3 9}$ & 0 & 0 \\
\hline Place Image & 0.6293 & 0.8 & 0.7078 & $\mathbf{0 . 8 4 4 4}$ & 0 \\
Product Beliefs & 0.5605 & 0.8362 & 0.7475 & 0.8144 & $\mathbf{0 . 8 3 9 1}$ \\
\hline
\end{tabular}

While convergent validity can be identified via composite reliability, discriminant validity can be assessed using AVE square root. According to the criterion for threshold value, Fornell and Larcker [13] suggested that the square root of AVE of each construct should be higher than the correlation with other construct. Table 3 shows that the square root of AVE of each construct (as identified in the bold number) have value higher than the correlations with other constructs. Since the measurement model have shown satisfactory measure for reliability and validity, thus all remaining items were further analyzed in the structural model. This study dropped some items 1) 4 items from place image, 2) destination belief 1 item, and 3) intention to visit 1 item. The final result is the final measure after deleting some items due to not qualifying the PLS validity and reliability requirement.

\subsection{Structural model}

After the measurement model was completed, the structural model assessment can be tested. The results from the structural model is shown in Figure 2. There are four R2 can be seen from Figure 2. R2 of product beliefs is 0.663 . R2 of intention to choose product is 0.559 , R2 of destination beliefs is 0.396 , and $\mathrm{R} 2$ of intention to visit is 0.488 . This suggests that place image is considerably strong in affecting product beliefs $(66.3 \%)$ and destination beliefs $(39.6 \%)$. Further, product beliefs explain intention to choose product quite strong with $55.9 \%$. Similarly, destination beliefs also explain intention to visit quite strong with $48.8 \%$, while the other $51.2 \%$ is explained by other factors.

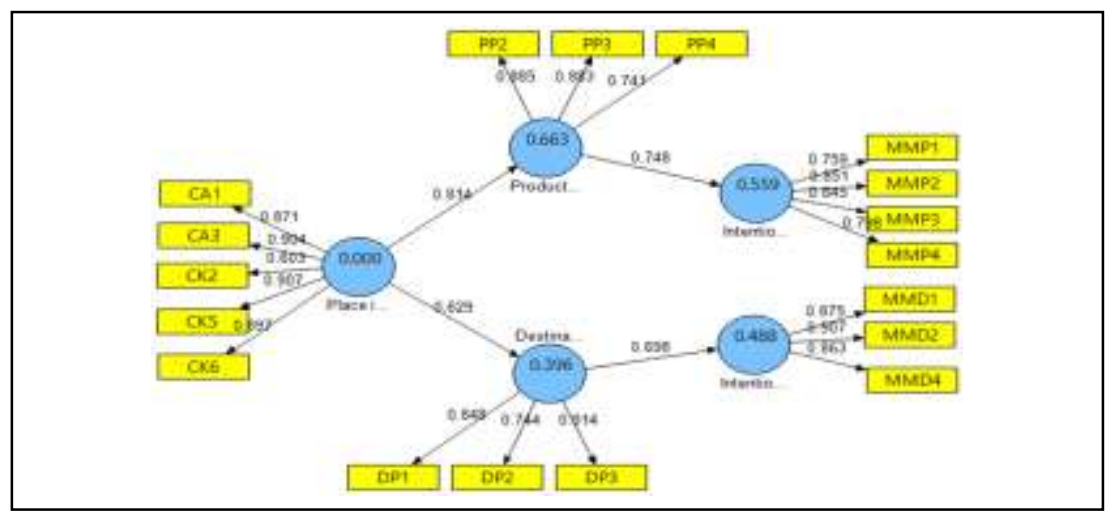

Figure 2. PLS Results 
Table 4. Path Coefficients

\begin{tabular}{|l|l|c|c|}
\hline $\begin{array}{c}\text { Independent } \\
\text { Variable }\end{array}$ & Dependent Variable & $\begin{array}{c}\text { Original Sample (Standardized } \\
\text { estimate) }\end{array}$ & $\begin{array}{c}\text { T Statistics } \\
\text { (|O/STERR|) }\end{array}$ \\
\hline $\begin{array}{l}\text { Destination } \\
\text { beliefs }\end{array}$ & $\begin{array}{l}\text { Intention to visit } \\
\text { Destination }\end{array}$ & 0.6983 & 17.0504 \\
\hline Place image & Destination beliefs & 0.6293 & 12.4538 \\
\hline Place image & Product beliefs & 0.8144 & 21.5048 \\
\hline Product beliefs & $\begin{array}{l}\text { Intention to choose } \\
\text { product }\end{array}$ & 0.7475 & 14.1675 \\
\hline
\end{tabular}

The structural model from PLS explained that all the relationships proposed were supported. This means that hypothesis 1 to hypothesis 4 were supported. The proposition that place image positively affect product beliefs (H1) was supported with significant $\beta=0.8144, p<0.01$ and $t$ statistics at 21.5048 . The proposition that place image positively affect destination beliefs (H2) was supported with significant $\beta=0.5293, \mathrm{p}<0.01$ and $\mathrm{t}$ statistics at 12.4538 . The proposition that product beliefs positively affect intention to choose product $(\mathrm{H} 3)$ was supported with significant $\beta=0.7475, \mathrm{p}<0.01$ and $t$ statistics at 14.1675. The proposition that destination beliefs positively affect intention to visit (H4) was supported with significant $\beta=0.6983, p<0.01$ and t statistics at 17.0504 . The results of this study have important implications for batik industry and Yogyakarta as destination where the image and reputation of Yogyakarta can be managed to support the local product such as batik.

\section{Discussion}

This study proposes four hypotheses that combine between tourism destination image (TDI) concept to product country image concept (PCI). The first hypothesis was supported thus place image influences product beliefs. This can be interpreted that positive image of an area may lead to public's positive perception on the product produced by the related area. Batik Yogyakarta has long been preserved and developed particularly in the kingdom family. Public perception on the quality of life in Yogyakarta, quality of education, quality of health, hospitality of the local, peaceful and pleasant area can assist people to think positively about local product produced in Yogyakarta. The positive perception by people that batik Yogyakarta is a good product, is made by expert, innovative and have high historical values can be because of long time efforts made by people of Yogyakarta in building their positive image for their region. The result of this study supports the previous literature in the same context by Elliot and Papadopoulos [9] and DeNisco, et al., [8].

Similarly, the second hypothesis is place image positively affect destination beliefs. Relating to batik industry, Yogyakarta image as a whole has positive impact on public beliefs about Yogyakarta as a destination. The better the image the better the destination beliefs. This means that Yogyakarta image will lead people to think that when in Yogyakarta, they should find many interesting places to visit such as the Kraton (kingdom palace), the temples, the beach, the volcano and the shopping areas. So even though someone has never visit Yogyakarta, but by being exposed to the positive information about Yogyakarta, people will start to build beliefs about Yogyakarta as a place to visit. The result of this study thus supports the previous literature from Elliot and Papadopoulos [9] and DeNisco, et al., [8].

Hypothesis 3 and hypothesis 4 proposing that when customers build beliefs about place and local product, then most possibly that their behavior should show positive response. Beliefs is prerequisite for future behavior. Thus, business managers, government and 
education institutions should understand and be clear that there are processes to make consumers choose the offerings. These hypotheses give us some views that even though image may lead to direct impact on behavioral intentions, building "beliefs" in product and in place should lead to better response from consumers. The finding from this study supports the previous literature from Elliot and Papadopoulos [9] and DeNisco, et al., [8].

\section{Conclusion and recommendation}

Place image as an intangible cue may influence the behavior of the consumers. The marketing discipline has recognized the country-of-origin effect on products with brand where the image of country or place may influence consumers' perception on product. By using this logic, narrower area such as the image of territory could also influence the local products receptivity by the market. The objective of this study is to find the influence of place image on product and destination beliefs as well as further on the receptivity or intention to choose the product and to visit the place. Batik industry in Yogyakarta is chosen to test the model. Purposive sampling was chosen where respondents were individual who are not the residents of Yogyakarta but familiar with Yogyakarta. There were four proposed hypotheses built for this research and the PLS-SEM suggests that: 1) The influence of place image on product beliefs is supported. 2) The influence of place image on destination beliefs is supported. 3) The influence of product beliefs on intention to choose product is supported. 4) The influence of destination beliefs on intention to visit the destination is supported.

The theoretical implications are that the combination of tourism destination image and product image could be modeled in one research framework, so that it could provide the theoretical base on place image and product image relationships. Secondly, testing the research model in batik industry provides the wider evidence in different industry on the application of integrative model between tourism destination image and product country image. The practical contributions are that the statistical support to the research model should be translated by the managers, public policy makers as well as academician that marketing strategy on local products should consider the reputation or image of the place where the local product originally comes from. This strategy could add differentiation on the products as well as helps the market to easily recognized and build positive image to those local products.

\section{Acknowledgements}

The authors are thankful to DP2M Ministry of Research, Technology and Higher Education of the Republic of Indonesia and Universitas Islam Indonesia, Yogyakarta, for supporting this research and providing the necessary facilities.

\section{References}

[1] Z. U. Ahmed, J. P. Johnson, X. Yang, C. K. Fatt, H. S. Teng, and L. C. Boon, Int. Mark. Rev. (2004)

[2] F. Ali, S. M. Rasoolimanesh, M. Sarstedt, C. M. Ringle, and K. Ryu, Int. J. Contemp. Hosp. Manag. (2018)

[3] M. Andéhn, F. Nordin, and M. E. Nilsson, J. Consum. Behav. 15, 225 (2016)

[4] A. Beerli and J. D. Martin, Ann. Tour. Res. 31, 657 (2004)

[5] C.-F. Chen and D. Tsai, Tour. Manag. 28, 1115 (2007)

[6] W. W. Chin, in Handb. Partial Least Squares (Springer, 2010), pp. 655-690 
[7] A. De Nisco, N. Papadopoulos, and S. Elliot, Int. Mark. Rev. (2017)

[8] Q. Deng and M. Li, J. Travel Res. 53, 69 (2014)

[9] C. M. Echtner and J. R. B. Ritchie, J. Travel Res. 31, 3 (1993)

[10] S. Elliot and N. Papadopoulos, J. Bus. Res. 69, 1157 (2016)

[11] S. Elliot, N. Papadopoulos, and L. Szamosi, Anatolia 24, 5 (2013)

[12] M. Florek, J. Int. Stud. 6, (2013)

[13] C. Fornell and D. F. Larcker, J. Mark. Res. 18, 39 (1981)

[14] M. G. Gallarza, I. G. Saura, and H. C. García, Ann. Tour. Res. 29, 56 (2002)

[15] D. Gertner, Place Brand. Public Dipl. 7, 91 (2011)

[16] J. J. Hahm and K. Severt, J. Hosp. Tour. Insights (2018)

[17] J. Hahm and Y. Wang, J. Travel Tour. Mark. 28, 165 (2011)

[18] J. F. Hair, M. Sarstedt, C. M. Ringle, and J. A. Mena, J. Acad. Mark. Sci. 40, 414 (2012)

[19] C. M. Han, J. Mark. Res. 26, 222 (1989)

[20] C. K. A. Hawkins, Del I, Best Roger J., Consumer Behavior: Building Marketing Strategy, 8th ed. (McGraw-Hill, Boston, 2001)

[21] K. Kaplanidou, J. Sport Tour. 14, 249 (2009)

[22] C. King, N. Chen, and D. C. Funk, J. Hosp. Tour. Res. 39, 3 (2015)

[23] B. Leisen, J. Serv. Mark. (2001)

[24] M. Mody, J. Day, S. Sydnor, X. Lehto, and W. Jaffé, Tour. Manag. Perspect. 24, 139 (2017)

[25] S. Pike and C. Ryan, J. Travel Res. 42, 333 (2004)

[26] R. Ratna, A. Hidayat, and M. Muhajir, Int. J. Res. Stud. Manag. (2019)

[27] R. Roostika, Russ. J. Agric. Socio-Economic Sci. 6, 97 (2019)

[28] S. Stepchenkova, (2015)

[29] H. Zhang, X. Fu, L. A. Cai, and L. Lu, Tour. Manag. 40, 213 (2014)

[30] M. Zhang and D. Merunka, Asia Pacific J. Mark. Logist. (2015) 